\title{
Endogenous Expression of Type II cGMP-dependent Protein Kinase mRNA and Protein in Rat Intestine

\author{
Implications for Cystic Fibrosis Transmembrane Conductance Regulator
}

Tilman Markert, * Arie B. Vaandrager, ${ }^{\ddagger}$ Stepan Gambaryan, ${ }^{*}$ Doris Pöhler, ${ }^{*}$ Christoph Häusler, ${ }^{*}$ Ulrich Walter, * Hugo R. De Jonge, ${ }^{\star}$ Thomas Jarchau, ${ }^{\star}$ and Suzanne M. Lohmann *

${ }^{*}$ Medizinische Universitäts-Klinik, Klinische Biochemie \& Pathobiochemie, 97080 Würzburg, Germany; ${ }^{\ddagger}$ Erasmus University, Department of Biochemistry, Medical Faculty, 3000 DR Rotterdam, The Netherlands

\begin{abstract}
Certain pathogenic bacteria produce a family of heat stable enterotoxins (STa) which activate intestinal guanylyl cyclases, increase cGMP, and elicit life-threatening secretory diarrhea. The intracellular effector of cGMP actions has not been clarified. Recently we cloned the cDNA for a rat intestinal type II cGMP dependent protein kinase (cGK II) which is highly enriched in intestinal mucosa. Here we show that cGK II mRNA and protein are restricted to the intestinal segments from the duodenum to the proximal colon, with the highest amounts of cGK II protein in duodenum and jejunum. cGK II mRNA and protein decreased along the villus to crypt axis in the small intestine, whereas substantial amounts of both were found in the crypts of cecum. In intestinal epithelia, cGK II was specifically localized in the apical membrane, a major site of ion transport regulation. In contrast to cGK II, cGK I was localized in smooth muscle cells of the villus lamina propria. Short circuit current $\left(I_{S C}\right)$, a measure of $\mathrm{Cl}^{-}$secretion, was increased to a similar extent by STa and by 8-Br-cGMP, a selective activator of cGK, except in distal colon and in monolayers of T84 human colon carcinoma cells in which cGK II was not detected. In human and mouse intestine, the cyclic nucleotide-regulated $\mathrm{Cl}^{-}$conductance can be exclusively accounted for by the cystic fibrosis transmembrane conductance regulator (CFTR) $\mathrm{Cl}^{-}$channel. Viewed collectively, the data suggest that cGK II is the mediator of STa and cGMP effects on $\mathrm{Cl}^{-}$transport in intestinal epithelia. ( $J$. Clin. Invest. 1995. 96:822-830.) Key words: chloride secretion - cystic fibrosis - sodium chloride absorption - heat stable enterotoxin $\cdot$ guanylyl cyclase
\end{abstract}

Tilman Markert and Arie B. Vaandrager contributed equally to the work contained in this manuscript.

Address correspondence to Dr. Tilman Markert, Medizinische Universitäts-Klinik, Klinische Biochemie \& Pathobiochemie, Josef Schneider Str. 2, 97080 Würzburg, Germany. Phone: 931201 3137; FAX: 931 2013153

Received for publication 12 December 1994 and accepted in revised form 13 April 1995.

1. Abbreviations used in this paper: cAK, cAMP dependent protein kinase; CFTR, cystic fibrosis transmembrane conductance regulator; cGK, cyclic GMP dependent protein kinase; STa, heat stable enterotoxin.

J. Clin. Invest.

(C) The American Society for Clinical Investigation, Inc.

0021-9738/95/08/0822/09 \$2.00

Volume 96, August 1995, 822-830

\section{Introduction}

Certain of the profound effects of two major signal transduction systems, that of atrial natriuretic peptide (ANP) ${ }^{1}$ and endothelium derived relaxing factor (EDRF) or nitric oxide (NO), on the cardiovascular and renal systems are mediated by cGMP (1). In intestine, ANP increases cGMP and triggers ion fluxes and secretory responses $(2,3)$. Heat stable enterotoxins (STa) also increase cGMP in intestine and can cause lethal secretory diarrhea (4). Whereas cells in the lamina propria of intestinal villi contain a transmembrane guanylyl cyclase (GC-A) responsive to ANP $(2,3)$, both STa and an endogenous intestinal peptide called guanylin activate a different transmembrane receptor guanylyl cyclase, GC-C, in epithelial cells to increase cGMP (reviewed in references 5-7). Subsequent events triggered by STa leading to changes in intestinal fluid and electrolyte transport and secretory diarrhea are not entirely clear, however, increase in cGMP is thought to inhibit epithelial sodium chloride and water absorption and to activate epithelial chloride secretion (4). CFTR $\mathrm{Cl}^{-}$channels can fully account for cyclic nucleotide-elicited $\mathrm{Cl}^{-}$secretion in human and rat intestine since no electrogenic $\mathrm{Cl}^{-}$secretion is provoked by either cAMP or cGMP analogs or STa in intestinal epithelium of CF patients (7), and there is no $\mathrm{Cl}^{-}$secretion in response to guanylin in transgenic CF mice (8).

There are multiple effectors of cGMP action including cGMP gated channels, cGMP regulated phosphodiesterases, cGMP dependent protein kinases (cGK), and possibly cAMP dependent protein kinases (cAK) (1). Cyclic GMP crossactivation of cAK has been described as a major mechanism by which STa elicits CFTR $\mathrm{Cl}^{-}$channel activation in T84 and Caco-2 human colon carcinoma cell lines (9-11). Other studies on native intestinal epithelium however suggested that cGMP activation of $\mathrm{Cl}^{-}$secretion is mediated by a novel intestinal brush border isoform of cGK designated cGK II (reviewed in reference 7). In the present study we address the question of the endogenous physiological effector of cGMP in intestine by localization of cGK isoforms and measurement of cGMP-provoked $\mathrm{Cl}^{-}$secretion. Mammalian cGK isoforms cGK I $\alpha$ and I $\beta$ from bovine trachea and human placenta $(12,13)$ and cGK II from mouse brain and rat intestine $(14,15)$ have been recently cloned, facilitating development of probes used in the present investigation. Our results demonstrate that cGK II is strategically located in the epithelial brush border of certain intestinal segments in which a mediatory role for cGK II in STa and cGMP regulation of intestinal ion transport is indicated by functional studies.

\section{Methods}

Northern blot analysis. Total RNA was extracted using RNAzol B (Wak-Chemie, Bad Homburg) based on the method of Chomczynski 
et al. (16) and subsequently poly (A) RNA was prepared using an mRNA purification kit (Pharmacia-LKB, Freiburg). Northern blots were hybridized with ${ }^{32} \mathrm{P}$-labeled antisense RNA probes made by in vitro transcription from pGKII5-5, containing bp 741-1450 of the cGK II sequence (15), and were washed at $70^{\circ} \mathrm{C}$ with $2 \times$ SSPE $/ 0.1 \%$ SDS and subsequently with $0.1 \times$ SSPE $/ 0.1 \%$ SDS.

Intestinal segment preparation. For immunocytochemistry and in situ hybridization, intestinal tissue from male Sprague Dawley rats (200 grams) was perfusion-fixed with $4 \%$ paraformaldehyde. The intestinal segments isolated included the esophagus, stomach, duodenum, jejunum (within $25 \mathrm{~cm}$ after the pylorus), ileum ( $10 \mathrm{~cm}$ proximal to the ileocecal valve), cecum, and the ascending (proximal), transverse, descending, and sigmoid colon.

In situ hybridization. In situ hybridization was performed according to standard procedures (17). ${ }^{35} \mathrm{~S}$-labeled sense and antisense riboprobes, each corresponding to bp 741-1450 of the cGK II sequence, were prepared from linearized pGKII5-5 and then reduced to $\sim 150$-base fragments by alkaline hydrolysis. Tissue sections were hybridized overnight at $52^{\circ} \mathrm{C}$ with $50 \mathrm{ng}$ labeled RNA per ml hybridization buffer, subsequently washed with hybridization buffer at $50^{\circ} \mathrm{C}$, incubated with RNAse A $(187 \mu \mathrm{g} / \mathrm{ml})$ at $37^{\circ} \mathrm{C}$, and finally washed with $2 \times \mathrm{SSC}$ at $65^{\circ} \mathrm{C}$. After dehydration, the slides were dipped in Kodak NTB2 emulsion and exposed for 7-21 d at $4^{\circ} \mathrm{C}$ before developing and counterstaining with toluidine blue.

Antibody production and purification. Recombinant cGK II and cGK I $\beta$ were separately expressed in $E$. coli and purified for use as antigens for immunization of rabbits. The EcoRI-fragment of clone pGKIII $/ 5$ containing a partial cDNA of cGK II (15) was subcloned into the EcoRI-site of pET-5b (18) (Novagen, Madison, WI) to produce the plasmid pET-GKII for transforming the E. coli strain BL 21 (DE3). Gene splicing by overlap extension (19) was used to create a fusion gene composed of the complete coding region of $\mathrm{CGK} \mathrm{I} \beta$ and the secretion signal of $E$. coli hemolysin A from vector pTJ11 (20). This construction, originally designed for another purpose, was additionally used here to generate an antigen for antibody production after it was placed into pET5c for expression in $E$. coli as above. Under conditions in which cGK II and cGKI $\beta$ were each almost exclusively expressed in bacterial inclusion bodies, the latter were purified and subsequently solubilized in $7 \mathrm{M}$ urea. The solubilized inclusion bodies were subjected to preparative SDS-PAGE, and the cGK II or cGK I $\beta$ band excised, electroeluted, and used to immunize rabbits as described (21). For antibody purification, the purified cGK II antigen was bound to NHSactivated HiTrap affinity columns (Pharmacia-LKB, Uppsala) and polyclonal antibodies were passed over the columns which were then washed and eluted according to standard methods (22).

Immunocytochemistry. Frozen sections $(5 \mu \mathrm{m})$ were mounted on silane-coated glass slides and incubated with $30 \%$ human serum in PBS to decrease nonspecific staining, then incubated with either antiserum against cGK II (diluted 1:2,000 to 1:5,000), affinity purified antiserum against cGK II (diluted 1:400), or antiserum against cGK I $\beta$ (diluted 1:5,000) overnight. Labeling was performed using a peroxidase coupled anti-rabbit antibody (Dianova, Hamburg) followed by $0.25 \mu \mathrm{g} / \mathrm{ml} 9$ aminoethyl-carbazol in $0.1 \mathrm{M}$ sodium acetate and $0.02 \% \mathrm{H}_{2} \mathrm{O}_{2}$ for color development.

Enterocyte cell fractionation. Epithelial cells were isolated at 0$4^{\circ} \mathrm{C}$ from the jejunal-ileal segment of rat small intestine by everting segments on metal rods attached to a vibration apparatus (Vibromixer type E1 from Chemap A.G., Männedorf, Switzerland) and exposing them to vibration $(50 \mathrm{~Hz}$, amplitude $1.5 \mathrm{~mm}$ ) for $30 \mathrm{~min}$ in $0.14 \mathrm{M}$ $\mathrm{NaCl}$ containing $5 \mathrm{mM}$ EDTA ( $\mathrm{pH}$ 7.4). In other experiments, fractions enriched in epithelial cells from the villus tip (villus I), the mid villus (villus II) and the lower villus (villus III) regions were respectively obtained by exposing jejunal-ileal segments to sequential 10-min vibration periods. After insufflation of air into the intestinal segment, crypt cells were harvested during another 30-min vibration period. Epithelial cells were pelleted by low speed centrifugation. Sucrase activity, a marker for enterocyte differentiation, measured in a typical experiment,

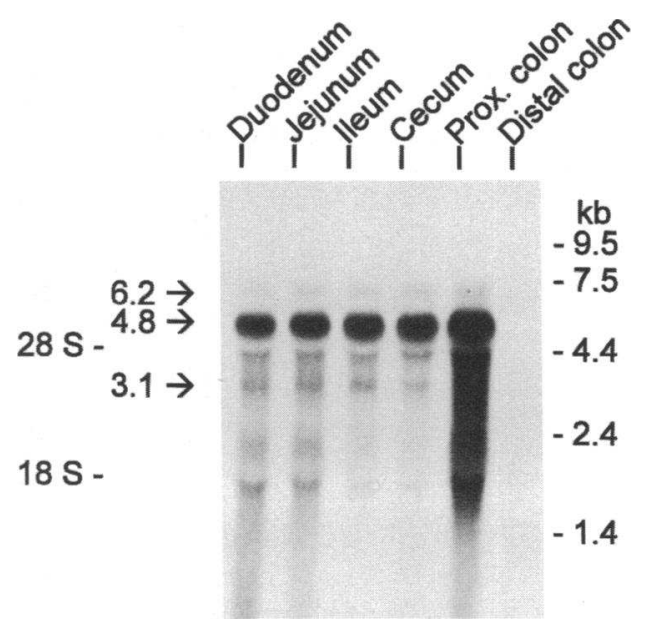

Figure 1. Northern blot analysis of cGK II mRNA present in enterocytes prepared from different segments of rat intestine. Total RNA samples $(15 \mu \mathrm{g})$ were hybridized with a ${ }^{32} \mathrm{P}$-labeled cGK II antisense RNA probe. RNA molecular weight standards stained with ethidium bromide were used to determine the size of cGK II transcripts $(6.2,4.8$, and 3.1 $\mathrm{kb})$. The location of the 28 and $18 \mathrm{~S}$ rRNA bands are also indicated.

was $248,165,106$, and $33 \mathrm{nmol} / \mathrm{mg}$ protein/min in the villus I, II, III and crypt preparations respectively (23).

Preparation of brush border caps $(B B)$ and brush border membrane vesicles (BBMV). Intact BB were released from jejunal-ileal segments by mechanical vibration for $25 \mathrm{~min}$ in $2.5 \mathrm{mM}$ Tris-buffered EDTA $(\mathrm{pH} 7.0)$ and were pelleted by low speed centrifugation $(1,500 \mathrm{~g}, 10$ $\mathrm{min}$ ) after the removal of nuclear aggegates with glasswool (3). BBMV were prepared from isolated rat intestinal villous cells or a human ileal segment by a freeze-thaw procedure and differential $\mathrm{MgSO}_{4}$ precipitation as described (24).

Western blot analysis. Mucosa from different segments of intestine was homogenized in PBS containing protease inhibitors $(5 \mu \mathrm{g} / \mathrm{ml} \mathrm{leu-}$ peptin, $1.5 \mathrm{mM}$ benzamidine, $200 \mathrm{U} / \mathrm{ml}$ aprotinin, $2 \mu \mathrm{g} / \mathrm{ml}$ pepstatin A, $10 \mu \mathrm{g} / \mathrm{ml}$ PMSF, $1 \mathrm{mM}$ EDTA) and samples were analyzed by Western blots using cGK II antiserum diluted $1: 400$ and $1 \mu \mathrm{Ci}^{125} \mathrm{I}$-protein $\mathrm{A}$.

Samples for Western blots of human colon carcinoma cells, enterocytes and their subcellular fractions, or brush borders and brush border membrane vesicles, were analyzed differently by labeling with cGK II antibody diluted 1:3,000, followed by anti-rabbit IgG coupled to peroxidase diluted 1/3,000 (Tago, Burlingame, $\mathrm{CA}$ ) and visualization by the enhanced chemiluminescence (ECL) method (Amersham, Braunschweig).

Short circuit current $\left(I_{S C}\right)$ measurements. Intestinal mucosa segments were isolated, and in some cases (i.e., cecum, proximal, and distal colon) the muscle layer was stripped off by blunt dissection. Mucosal segments were mounted in an Ussing chamber and short-circuit current $\left(\mathrm{I}_{\mathrm{sc}}\right)$ across an exposed area of the intestinal mucosa $\left(0.3 \mathrm{~cm}^{2}\right)$ was measured as previously described (25). For measurements of Isc across filter-grown monolayers of T84 cells (see below), a different type of Ussing chamber was used (26). The intestinal segments were incubated with purified heat stable enterotoxin (STa) and cyclic nucleotide analogs obtained from Sigma (Deisenhofen). The reported responses represent the maximal change in Isc provoked by a given secretogogue. Positive values for Isc denote a negative electrical charge flux from serosa to mucosa.

Cell culture. T84 and Caco-2 cells were obtained from ATCC and HT29-19A cells were a gift from Dr. C. L. Laboisse (Nantes, France). T84 cells were grown in Dulbecco's modified Eagle's medium (DME)/ Ham's F12 (1:1), $15 \mathrm{mM}$ Hepes, and 5\% fetal calf serum (FCS); Caco-2 cells in DME, $25 \mathrm{mM}$ Hepes, $1 \%$ nonessential amino acids, and 

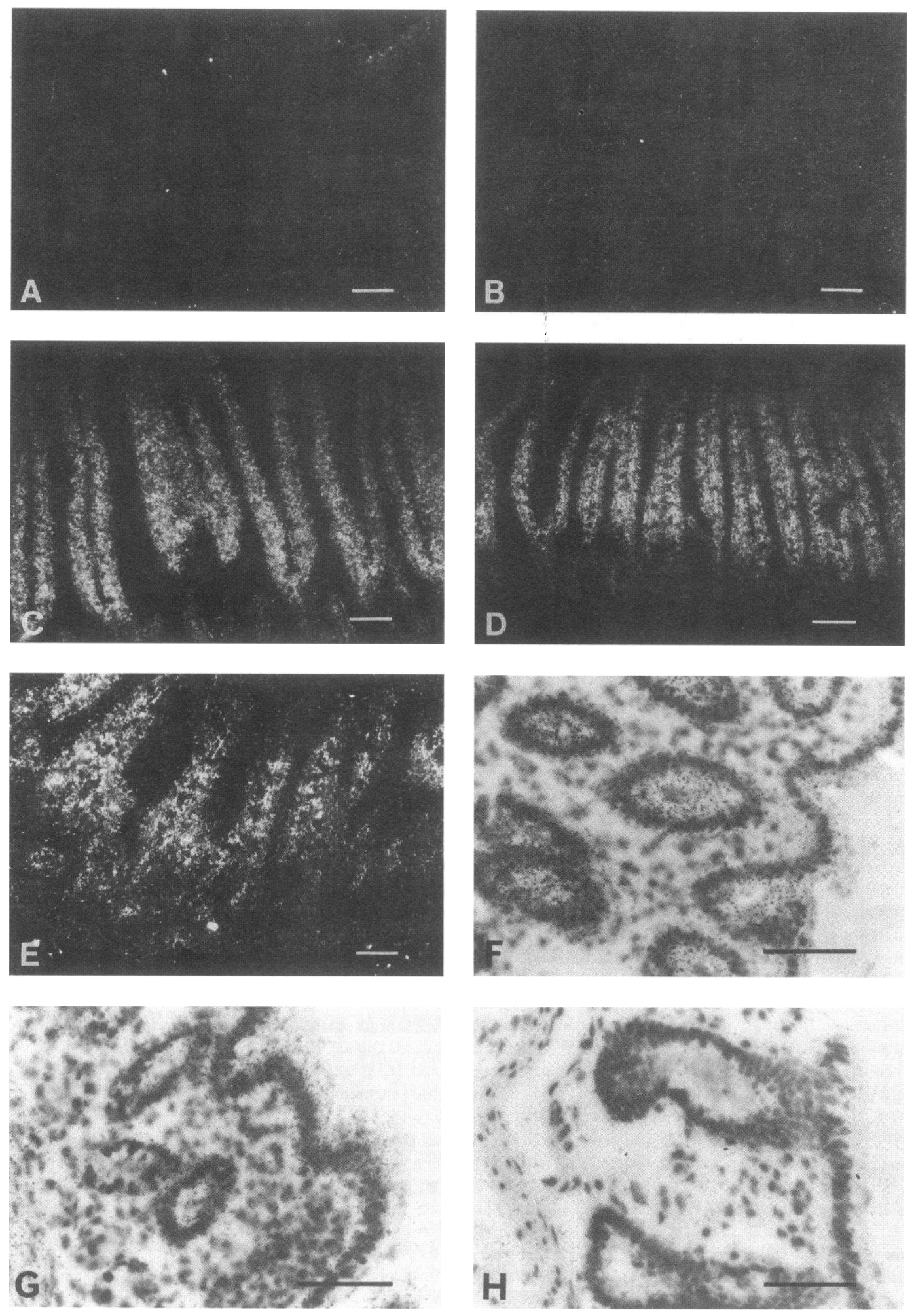

Figure 2. Localization of cGK II mRNA in different segments of rat intestine by in situ hybridization. The labeling in dark-field views $(A-E$, with intestinal lumen at top of section) appears as aggregates of silver grains, whereas in bright-field views $(F-H$, intestinal lumen at right side of sections) labeling appears as black spots. Specific labeling with an ${ }^{35}$ S-labeled cGK II antisense RNA was found in epithelial cells of duodenum $(C)$, jejunum $(D)$, ileum $(E)$, cecum $(F)$, and proximal colon $(G)$. No hybridization signal was found in distal colon $(H)$ and stomach $(A)$. A cGK II sense probe gave no significant labeling, as shown for duodenum $(B)$. Specific labeling extended along the crypt to the upper villus in duodenum, jejunum and ileum $(C-E)$, whereas specific labeling was greatest in the crypts, in comparison to the surface epithelium, in cecum $(F)$, found to a small extent in both crypts and surface epithelium of proximal colon $(G)$, and essentially undetectable in distal colon $(H)$. The bar represents $100 \mu \mathrm{m}$. 
$20 \%$ FCS; and HT 29-19A cells in DME and 10\% FCS. All media contained $40 \mathrm{mg} /$ liter penicillin and $90 \mathrm{mg} /$ liter streptomycin and cells were incubated in an atmosphere of $95 \% \mathrm{O}_{2} / 5 \% \mathrm{CO}_{2}$ at $37^{\circ} \mathrm{C}$. For Ussing chamber measurements, T84 cells were grown to confluence on tissue-culture-treated polycarbonate filters firmly attached to a polystyrene ring (6.4-mm diameter Transwell from Costar, Cambridge, MA) which was later inserted in a tight-fitting space separating the serosal and mucosal compartments of the Ussing chamber.

\section{Results}

Localization of cGK II mRNA in intestinal segments. Northern blot analysis of cGK II mRNA present in total RNA samples from enterocytes purified from rat intestinal segments is shown in Fig. 1. A major band of $4.8 \mathrm{~kb}$ and minor bands at 6.2 and $3.1 \mathrm{~kb}$ were observed to be similar to those found previously in rat jejunum mucosal scrapings (15). cGK II mRNA was present in all intestinal segments extending from the duodenum to the proximal colon but was notably absent from the distal colon. The distribution of cGK II mRNA was also investigated in enterocytes fractionated by exposure to mechanical vibration. cGK II mRNA was highly expressed in the tip and mid regions of the villus and decreased from the mid-villus to the crypt region (data not shown).

Consistent with the Northern blot data (Fig. 1), cGK II mRNA was shown by in situ hybridization to be most prominent in the small intestine segments of duodenum, jejunum, ileum, and cecum (Fig. 2, $C-F$ ), with lesser amounts in proximal colon (Fig. $2 G$ ). cGK II mRNA was undetectable in distal colon (Fig. $2 \mathrm{H}$ ), as well as stomach (Fig. $2 \mathrm{~A}$ ), and esophagus (not shown). The distribution of cGK II mRNA along the villus to crypt axis varied somewhat within the different segments. However, in the small intestine the strongest signal was observed in the mid villus region, with some labeling of crypts in duodenum and ileum. In the cecum, crypts were prominently labeled and the surface epithelium only moderately.

Endogenous cGK II protein expression in intestinal seg ments. The distribution of cGK II protein in mucosal scrapings analyzed on Western blots (Fig. $3 \mathrm{~A}$ ) reflected that of cGK II mRNA in isolated enterocytes (Fig. 1) insofar as the major amount was in small intestinal segments and was absent in stomach and distal colon. Similar to cGK II mRNA (data not shown), cGK II protein (Fig. $3 B$ ) decreased from the villus tip to the crypt of enterocytes.

With small exceptions, the distribution of cGK II observed by immunocytochemistry (Fig. 4) was basically similar to that observed by Western analysis (Fig. 3). In small intestinal segments (Fig. 4, $C-E$ ), cGK II labeling was most prominent in villi in comparison to crypts, whereas crypts were most strongly labeled in cecum (Fig. $4 F$ ). Again, cGK II was not detected in stomach (Fig. $4 \mathrm{~A}$ ) and distal colon (Fig. $4 \mathrm{H}$ ). In comparison to the distribution of cGK II mRNA observed by in situ hybridization, that observed by immunocytochemistry for cGK II protein in small intestine was shifted upwards in the direction of the villus. That is, compared to cGK II mRNA, less cGK II protein was observed in crypt cells, and more was observed in the villous tips in small intestine.

Whereas cGK II mRNA labeling by in situ hybridization covered a broad area representing the villous epithelial cells, immunocytochemical labeling was restricted to the epithelial cell microvilli or apical brush border. Faint labeling of the epi-
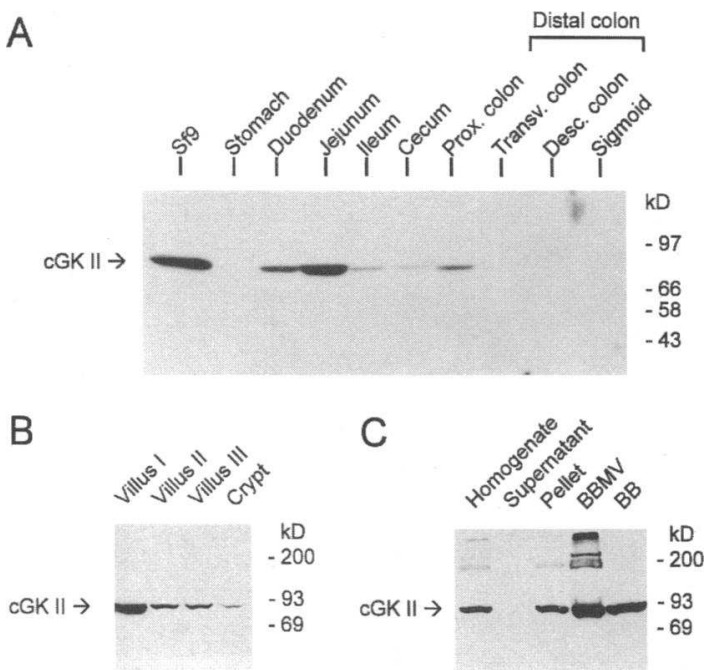

Figure 3. Western blots of endogenous cGK II in rat intestine. (A) cGK II present in mucosal scrapings (200 $\mu \mathrm{g}$ protein each) from different intestinal segments. cGK II was identified by its migration like a recombinant cGK II from Sf9 cell lysates (10 $\mu \mathrm{g}$ ) ( $\mathrm{Sf} 9$ clone from D.P. U.W., S.M.L., and T.J., unpublished results) and was detected using a specific antiserum and ${ }^{125}$ I-labeled Protein A. (B) cGK II present in villus and crypt fractions ( $15 \mu \mathrm{g}$ protein each) prepared from enterocytes isolated from the jejunum/ileum. Blots were labeled using cGK II specific antiserum and the ECL method. (C) cGK II detected in fractions ( $15 \mu \mathrm{g}$ protein each) made from enterocytes obtained from jejunal and ileal segments. Shown are the whole homogenate, as well as supernatant and pellet fractions derived from it by $100,000 \mathrm{~g}$ centrifugation. Also shown are preparations of brushborder membrane vesicles (BBMV) and brushborder caps (BB). Blots were processed as described in $B$ ).

thelial cell itself appeared to be non-specific since it diminished in labelings performed with affinity-purified antibody, whereas all other labeling was unchanged (see Fig. $5 \mathrm{~A}$ ). Results obtained from Western analysis of subcellular fractions of enterocytes from jejunum-ileum (Fig. $3 C$ ) agreed with the brush border localization of cGK II observed in small intestine by immunocytochemistry (Fig. 4). cGK II was found exclusively in the membrane pellet after $100,000 \mathrm{~g}$ centrifugation of homogenates and was also shown to be enriched in fractions of brush border membrane vesicles and brush border caps. The latter fractions both represent microvilli including the cytoskeleton, except that the terminal web is absent from the brush border membrane vesicle fraction (27).

Comparison of the localization of $c G K I$ and $c G K ~ I I$. The expression of cGK I and cGK II detected by immunocytochemistry in intestinal mucosa of duodenum is strikingly distinct (Fig. 5). Whereas cGK II is localized in the brush border of epithelial cells (Fig. $5 A$ ), cGK $I$ is exclusively in smooth muscle cells of the villus lamina propria (Fig. $5 B$ ) and the major smooth muscle layers of the intestinal wall (data not shown). Faint staining of the brush border by cGK I antibody appeared to be unspecific since it was not eliminated by preabsorption of the antibody with cGK I, whereas staining of the lamina propria smooth muscle cells was (not shown). The differential localization of cGK II and cGK I is supported by the results of Western blots showing detection of only cGK II in enterocytes (Fig. $6 \mathrm{~A}$ ) and only cGK I in smooth muscle tissue (SMC) (Fig. $6 B$ ). In addition, cGK I mRNA (7 kb) was not 

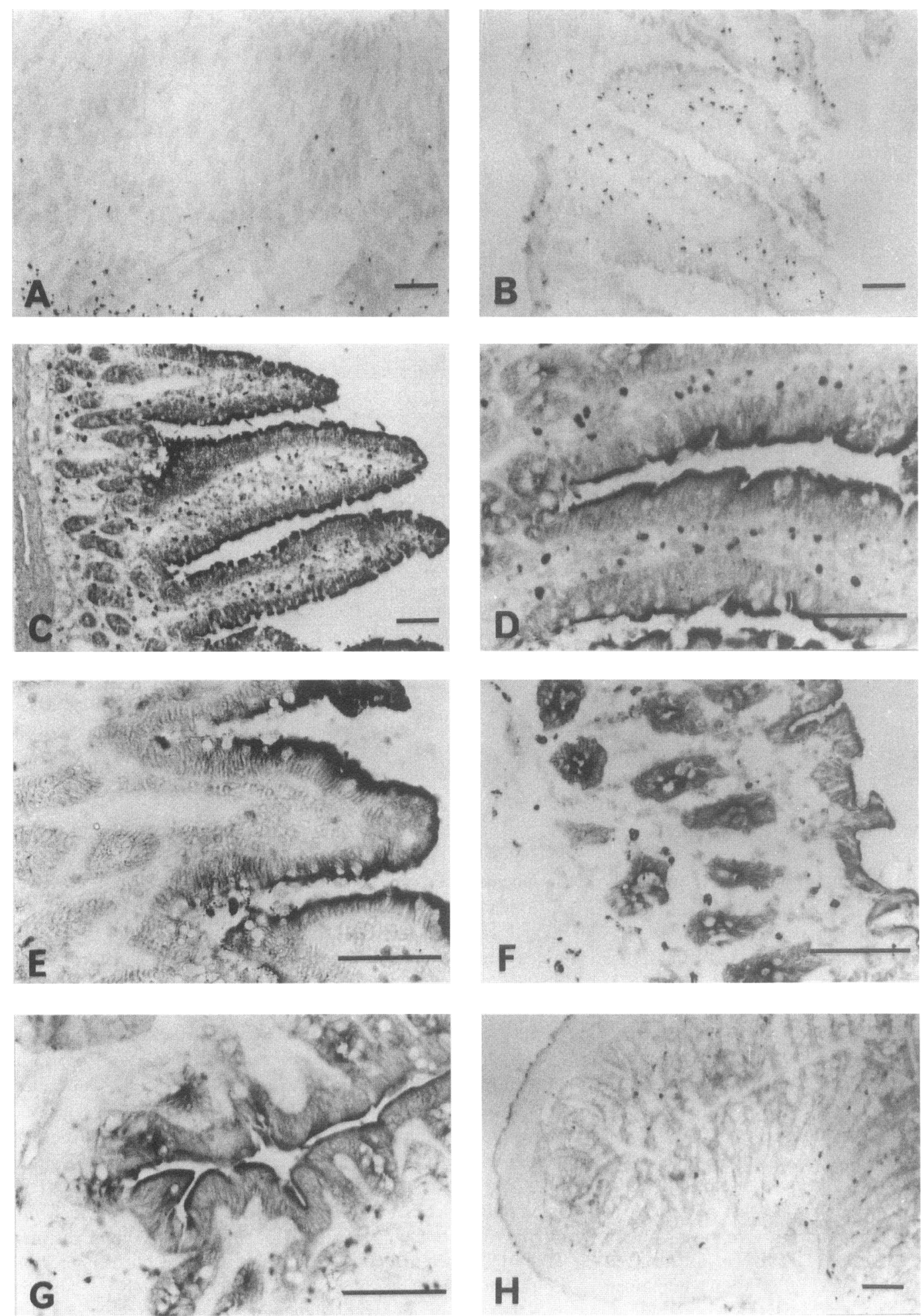

Figure 4. Localization of cGK II in different segments of rat intestine by immunoperoxidase cytochemistry. Staining of cGK II by specific antibody was observed $(C-G)$ in duodenum $(C)$, jejunum $(D)$, ileum $(E)$, cecum $(F)$, and proximal colon $(G)$. No specific staining was observed in stomach $(A)$, and distal colon $(H)$. Unspecific labeling observed with preimmune serum is shown for duodenum $(B)$. In general, cGK II labeling of the brush border microvilli of epithelial cells was observed. In duodenum, jejunum, and ileum $(C-E)$, the labeling extended from the upper part of the crypts to the tip of the villi. The labeling was greater in the crypt cells than the surface epithelium of cecum $(F)$, less in crypt cells and surface epithelium of proximal colon $(G)$, and essentially undetectable in distal colon $(H)$. The bar shown represents $100 \mu \mathrm{m}$. 

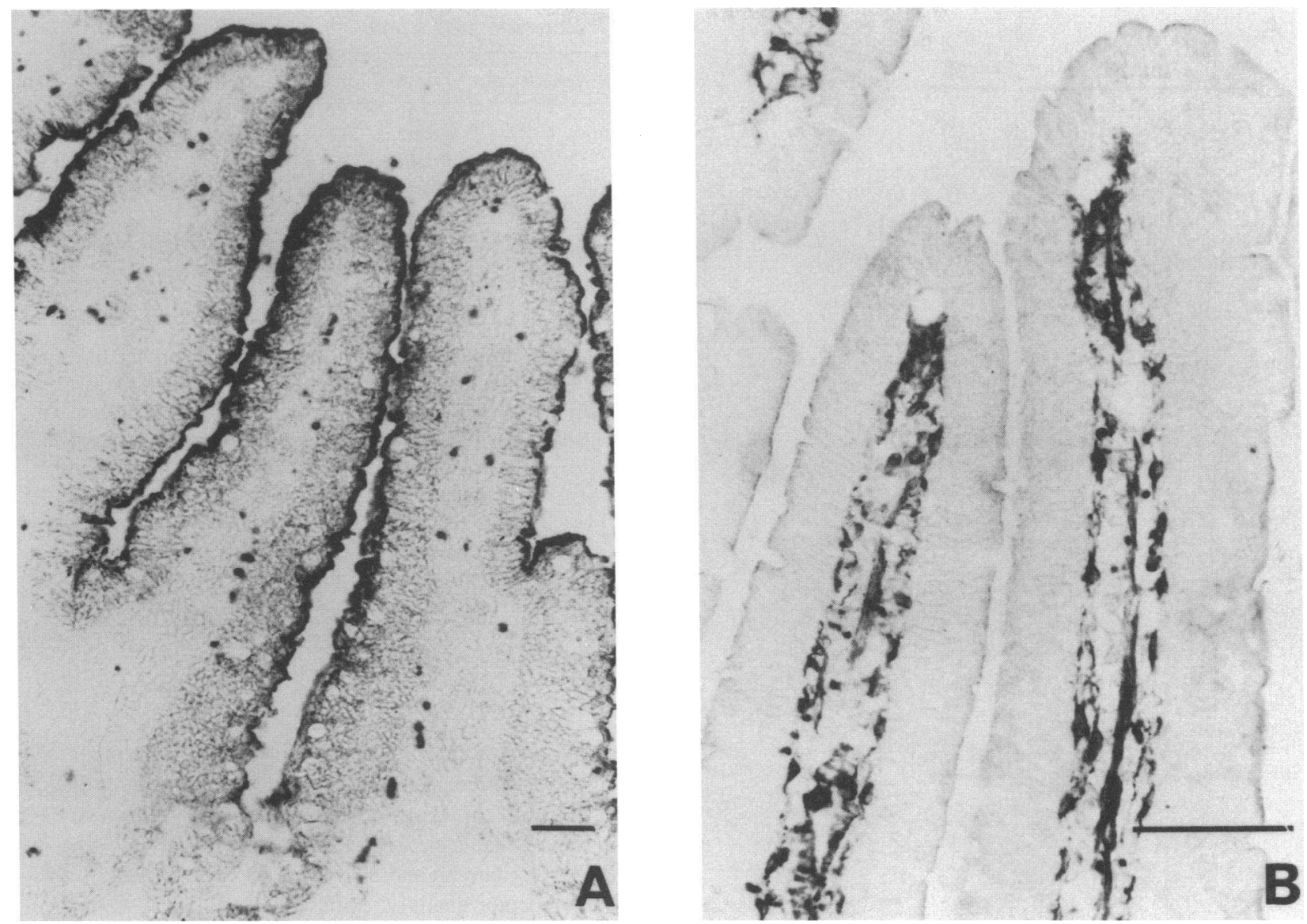

Figure 5. Comparison between cGK II and cGK I expression in the duodenum. Immunhistochemistry was performed using $(A)$ affinity purified antiserum against cGK II, and $(B)$ rabbit antiserum specific for cGK I. The bar represents $100 \mu \mathrm{m}$.

detected in poly (A) from an intestinal mucosa scraping (results not shown).

Regulation of intestinal $\mathrm{Cl}^{-}$secretion. Ussing chamber measurements of $\mathrm{Cl}^{-}$secretion ( $\left.\mathrm{I}_{\mathrm{sC}}\right)$ in mucosa strips from different intestinal segments is shown in Table I. STa, 8-BrcGMP, and 8-Br-cAMP cause an increase in $\mathrm{I}_{\mathrm{SC}}$ with certain notable differences. The response to 8-Br-cAMP is consistently greater than that of the other two agents, except in cecum, in which prominent labeling of cGK II mRNA and protein was observed in crypts, a major site of $\mathrm{Cl}^{-}$secretion. Furthermore, in distal colon, where cGK II is absent, the response to 8-BrcAMP is preserved, whereas that of the agents which increase cGMP is not. It should be noted that these experiments were performed in the presence of indomethacin since otherwise effects of STa on cAMP hydrolysis have been observed in colon (28). Whereas STa caused a large increase in Isc in both human colon carcinoma T84 cells and native intestine, 8-Br-cGMP, a selective activator of cGK (29), could mimic this only in intestinal segments containing cGK II, and not in T84 cells (Table I). Thus the mechanism by which STa activates $\mathrm{Cl}^{-}$secretion in T84 cells appears to differ from that of native intestine (see Discussion).

Absence of cGK II and cGK I in human colon carcinoma cell lines. Because of the frequent use of human colon carcinoma cell lines as models of intestinal cell function in response to cGMP (see Discussion), we investigated the presence of
cGK II and cGK I in such cells. Neither cGK II nor cGK I were detected in human T84, Caco-2, or HT29-19A cells at the film exposure ( $2 \mathrm{~min}$ ) shown in Fig. 6 or after a 10-fold longer exposure (not shown). Both antibodies crossreact with their respective human antigens, as seen for CGK II in human BBMV (Fig. 6 A), and as has been shown for cGK I in human platelets (30). The lower band (Fig. $6 \mathrm{~A}$ ) observed in the cell lines is considered to be unspecific rather than a degradation product of cGK II since cells were directly lysed in boiled SDS.

\section{Discussion}

STa enterotoxin-induced diarrhea causes many infant deaths in developing countries, is a leading cause of morbidity and death in domestic animals, and is considered a major cause of traveler's diarrhea (reviewed in reference 5). cGMP concentration increases elicited by STa result in net fluid secretion through the activation of epithelial apical $\mathrm{Cl}^{-}$transport and inhibition of coupled $\mathrm{NaCl}$ absorption (7). Both cGK II mRNA and protein were found only in intestinal segments between and including the duodenum and proximal colon. They were notably absent in the distal colon where STa and 8-Br-cGMP were unable to cause $\mathrm{Cl}^{-}$secretion. Furthermore, cGK II was localized by in situ hybridization, immunocytochemistry, and fractionation to intestinal epithelial cells. At the subcellular level, cGK II protein was specifically localized to the epithelial cell brush 
A
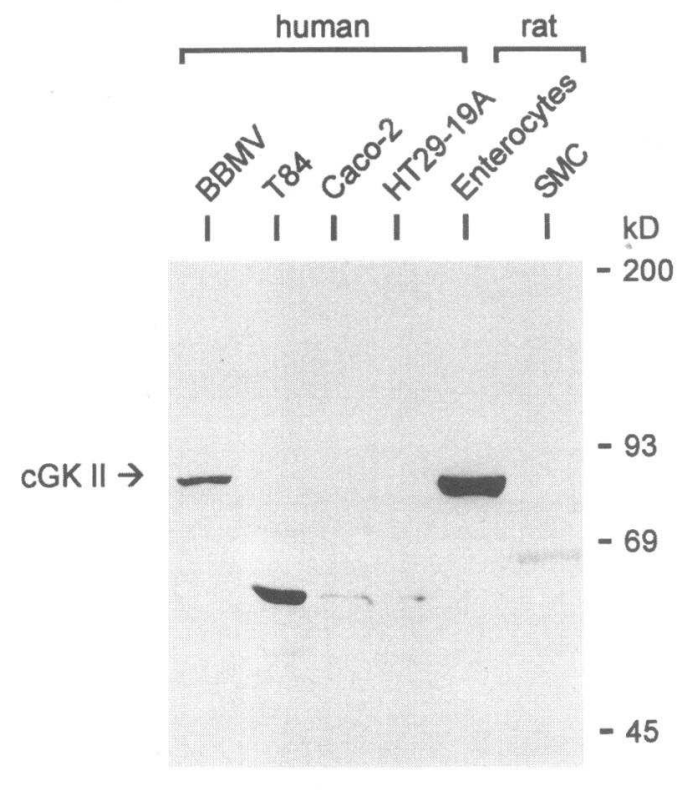

B

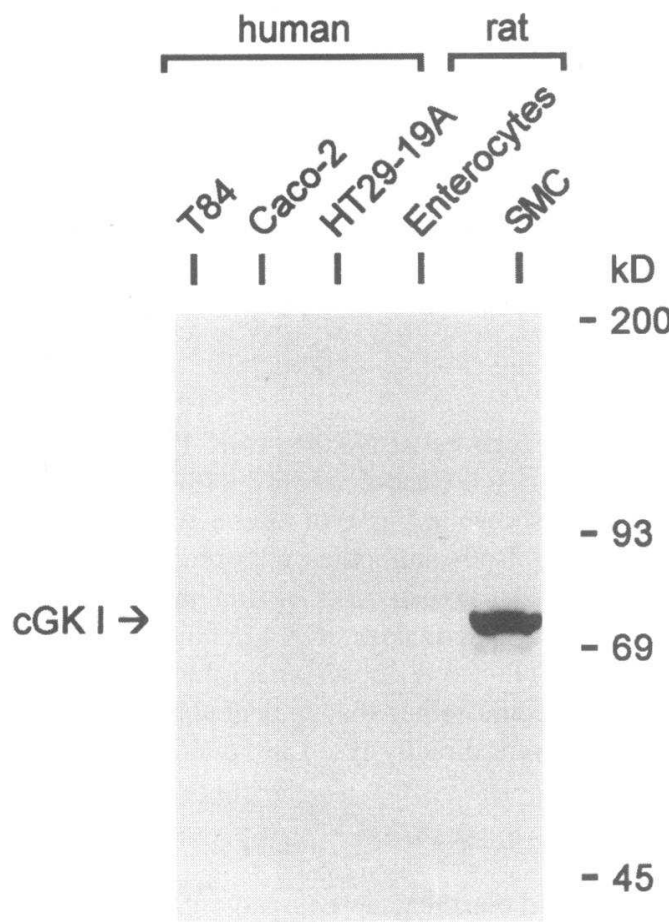

Figure 6. Western blot of GK II $(A)$ and cGK I $(B)$ in intestinal cell lines. Samples $(20 \mu \mathrm{g})$ represent homogenates made from human brush border membrane vesicles (BBMV), T84, Caco-2, and HT29-19A cell lines, jejunal-ileal enterocytes, and jejunal intestinal smooth muscle cells (SMC) from which the mucosal layer had been removed by scraping. The blot was labeled using specific antibodies and the ECL method.

border. This localization is consistent with that of the membrane guanylyl cyclase (GC-C) activated by STa and guanylin, as well as the localization of potential targets of cGMP action, CFTR and transporters for $\mathrm{NaCl}$ absorption (discussed below). In contrast, the localization of cGK I in smooth muscle cells of
Table I. Increment in Isc $\left(\mu \mathrm{A} / \mathrm{cm}^{2}\right)$

\begin{tabular}{lccc}
\hline Intestinal segment & STa & 8-Br-cGMP & 8-Br-cAMP \\
\hline Jejunum & $35 \pm 9$ & $43 \pm 7$ & $72 \pm 9$ \\
Ileum & N.D. & $49 \pm 6$ & $85 \pm 10$ \\
Cecum & $132 \pm 19$ & $136 \pm 16$ & $142 \pm 21$ \\
Proximal colon & $35 \pm 8$ & $30 \pm 4$ & $68 \pm 14$ \\
Distal colon & $2 \pm 2$ & $3 \pm 1$ & $79 \pm 11$ \\
T84 cells & $41 \pm 5$ & $3 \pm 2$ & $95 \pm 16$ \\
& & & \\
\hline
\end{tabular}

Ussing chamber measurements of the increment in short circuit current induced by STa, 8-Br-cGMP, and 8-Br-cAMP in segments of rat intestinal mucosa and in filter-grown monolayers of T84 cells. After a 10min preincubation in the presence of $0.1 \mathrm{mM}$ amiloride (mucosal side) and $10 \mu \mathrm{M}$ indomethacin (serosal side), either a saturating dose (0.5 $\mu \mathrm{M})$ of STa, or a maximal dose of 8-Br-cGMP $(0.2 \mathrm{mM})$ or 8 -Br-cAMP $(1 \mathrm{mM})$ was added to the bath and the maximal increment in $\mathrm{I}_{\mathrm{sc}}$ determined. The rise in $\mathrm{I}_{\mathrm{sc}}$ was abolished in medium in which $\mathrm{Cl}^{-}$and $\mathrm{HCO}_{3}^{-}$was replaced by gluconate, or was typically inhibited by subsequent serosal addition of either $0.1 \mathrm{mM}$ bumetanide, an inhibitor of $\mathrm{Na}$ $\mathrm{K}-2 \mathrm{Cl}$ co-transport, or $5 \mathrm{mM}$ barium, an inhibitor of $\mathrm{K}$ channels. Data represent mean values $\pm \operatorname{SEM}(n=6)$.

villi lamina propria, and its absence in mucosal scrapings and enterocytes, is not consistent with a role of cGK I in epithelial cell ion transport processes underlying secretory diarrhea.

Substances that increase $\mathrm{Cl}^{-}$secretion in the intestine include ANP, or guanylin and STa $(2,3,8)$, which bind to transmembrane receptor guanylyl cyclases GC-A, or GC-C, respectively (31). ANP, unlike STa, does not directly stimulate colonic epithelial cells but possibly provokes $\mathrm{Cl}^{-}$secretion indirectly by release of a neurotransmitter in the submucosa (3). In situ hybridization with rat tissues showed GC-A mRNA expression in the villi lamina propria, whereas GC-C mRNA was found in epithelial cells $(2,32)$. In rat colon GC-C mRNA was present in colonic crypts and surface epithelium (2); in rat small intestine, GC-C mRNA was more prominent in villar than crypt epithelium, and highest in the mid villus region (32). A study of ${ }^{125} \mathrm{I}-\mathrm{STa}$ binding to its receptor in human and other mammalian intestines including rat, demonstrated that GC-C protein was greatest in enterocytes located near the basal half of the villi and in the proximal half of the crypts (33). The distribution of GC-C, but not GC-A, closely resembles that of cGK II, thus only GC-C is appropriately situated to generate cGMP that can activate cGK II in intestinal epithelial cells. An endogenous intestinal peptide named guanylin was identified as the physiological mammalian equivalent of the pathogenic toxin STa for activating GC-C (5). A clear consensus concerning the localization of guanylin production is not available since it has been proposed to be in Paneth cells (34), surface epithelial cells and epithelial cells of upper crypts $(2,35)$, and in enterochromaffin cells (36).

Potential targets of cGMP action for regulating ion transport are also located in intestinal epithelial cells. CFTR, which forms the major cyclic nucleotide regulated $\mathrm{Cl}^{-}$secretory channel in intestine (reviewed in references 7 and 8), is located in the apical plasma membrane of $\mathrm{Cl}^{-}$-secreting epithelia (37). CFTR mRNA has been shown to decrease from crypts to villi and from the duodenum to the distal colon of the rat and human intestinal tract $(38,39)$. The principal secretory activity of the 
small and large intestine resides in the crypt compartment (4, 40 ). However, a relatively minor contribution of the villus compartment to cAMP- and cGMP-provoked $\mathrm{Cl}^{-}$secretion is also feasible considering the recent identification of a cAMP-activated $\mathrm{Cl}^{-}$conductance, presumably CFTR, in rat intestinal villi (41) and the recent demonstration that villus-specific expression of human CFTR in CFTR $-/-$ mice results in the appearance of a modest Isc response (one fourth of wild type) to forskolin (42). Importantly, our present results found a correlation between the level of cGK II expressed in intestinal crypt cells (relatively high in cecum, low in small intestine, and absent in distal colon) and the ability of STa and 8-Br-cGMP, in contrast to 8-Br-cAMP, to stimulate electrogenic $\mathrm{Cl}^{-}$secretion. Furthermore, the magnitude of $\mathrm{Cl}^{-}$current stimulation by STa in comparison to 8-Br-cGMP was similar in all intestinal segments examined (Table 1). These findings strongly suggest that cGK II is the major mediator of STa and cGMP-provoked $\mathrm{Cl}^{-}$secretion in native intestinal epithelium and that STa does not use any other mechanism of $\mathrm{Cl}^{-}$current activation beyond that used by 8 -Br-cGMP.

The strong increase in cGK II mRNA and protein expression from crypt to midvillus observed in the small intestine suggests that cGK II may additionally modulate other transport systems in the villus compartment. One possibility is the villus cell brush border $\mathrm{Na}^{+}$absorptive process which is inhibited in most diarrheal diseases, and which is composed of a Na${ }^{+} / \mathrm{H}^{+}$exchanger (NHE) linked to a $\mathrm{Cl}^{-} / \mathrm{HCO}_{3}^{-}$exchanger $(43,44)$. Whereas several NHE forms have been described and cloned, of these only NHE-3 was both present in the apical rather than basolateral membrane and apparently epithelium specific (4446). In situ hybridization showed that NHE-3 mRNA was exclusively located in rat small intestinal villus cells and luminal epithelial cells of colon, and that NHE-3 protein was selectively localized in the brush border membrane (46). So far, the mechanism of cGMP inhibition of the intestinal NHE has been addressed only in chicken enterocytes in which cGMP acts indirectly via $\mathrm{Ca}^{2+}$ mobilization (47). Whether a similar mechanism operates in mammalian enterocytes, and whether cGK II plays a role in this process, remains to be elucidated.

Consistent with the proposed function of cGK II as an effector of cGMP-provoked intestinal $\mathrm{Cl}^{-}$secretion, patch-clamp experiments have demonstrated that both the catalytic subunit of cAK and cGK II (48, and manuscript in preparation), but not cGK I $(48,49)$ can activate CFTR in excised patches of CFTR-transfected NIH-3T3 fibroblasts and rat intestinal IEC-6 cells. Certain other studies have alternatively implicated either the cAMP-dependent protein kinase (cAK) $(9-11)$ or cGK I (50) as mediators of cGMP action on CFTR as well. One critical aspect of these studies, however, is that they were performed in cell lines (T84, Caco-2) which, at least in our experiments (Fig. 6), contain no detectable amounts of cGK II or cGK I. Therefore conclusions made from these cells are predestined to neglect any contribution of the missing kinases, thus such cells may be unsuitable models for cGMP regulation of ion transport. In one report, however, a CFTR-like $\mathrm{Cl}^{-}$conductance in excised patches of $\mathrm{T} 84$ cells was proposed to be regulated by an endogenous membrane-associated cGK (50), suggesting that some T84 cell clones may express cGK. Furthermore, unlike in intestine (3), STa can increase cGMP in T84 cells to submillimolar amounts (9) and could thereby activate cAK. In our studies in distal colon in which cGK II was absent as in the cell lines, STa however did not increase Isc by crossactivation of cAK, whereas the response to 8-Br-cAMP was intact (Table I).

Collectively, our results indicate that cGK II is a likely physiological mediator of the effects of STa and guanylin increases in cGMP via GC-C for regulation of ion transport in intestinal mucosa. cGK II is shown to be strategically located in epithelial cell brush borders of villi and crypts in order to mediate cGMP inhibition of $\mathrm{NaCl}$ absorption and stimulation of CFTR $\mathrm{Cl}^{-}$secretion. Functional studies also showed that absence of cGK II correlated with loss of the effects of cGMP, but not cAMP, on $\mathrm{Cl}^{-}$secretion. Further functional studies are now indicated to examine the role of cGK II as an intermediate in the cGMP signal transduction pathway regulating intestinal ion transport in normal and disease states.

\section{Acknowledgments}

We thank Monika Krafft-Rex and Esther van der Wiel for excellent technical assistance.

This work was supported by the Deutsche Forschungsgemeinschaft (Ko 210/11-3 and SFB 355) and by the Netherlands Organization for Scientific Research.

\section{References}

1. Schmidt, H. H. H. W., S. M. Lohmann, and U. Walter. 1993. The nitric oxide and cGMP signal transduction system: regulation and mechanism of action. Biochim. Biophys. Acta. 1178:153-175.

2. Li, Z., and M. F. Goy. 1993. Peptide-regulated guanylate cyclase pathways in rat colon: in situ localization of GCA, GCC, and guanylin mRNA. Am. J. Physiol. 265:G394-G402.

3. Vaandrager, A. B., A. G. M. Bot, J. De Vente, and H. R. De Jonge. 1992. Atriopeptins and Escherichia coli enterotoxin STa have different sites of action in mammalian intestine. Gastroenterology. 102:1161-1169.

4. Field, M., M. C. Rao, and E. B. Chang. 1989. Intestinal electrolyte transport and diarrheal desease. N. Engl. J. Med. 321:800-806 and 879-883.

5. Currie, M. G., K. F. Fok, J. Kato, R. J. Moore, F. K. Hamra, K. L. Duffin, and C. E. Smith. 1992. Guanylin: An endogenous activator of intestinal guanylate cyclase. Proc. Natl. Acad. Sci. USA. 89:947-951.

6. Schulz, S., C. K. Green, P. S. T. Yuen, and D. L. Garbers. 1990. Guanylyl cyclase is a heat-stable enterotoxin receptor. Cell. 63:941-948.

7. Vaandrager, A. B., and H. R. De Jonge. 1994. Effect of cyclic GMP on intestinal transport. Adv. Pharmacol. 26:253-283.

8. Cuthbert, A. W., M. E. Hickman, L. J. MacVinish, M. J. Evans, W. H. Colledge, R. Ratcliffe, P. W. Seale, and P. P. A. Humphrey. 1994. Chloride secretion in response to guanylin in colonic epithelia from normal and transgenic cystic fibrosis mice. Br. J. Pharmacol. 112:31-36.

9. Forte, L. R., P. K. Thorne, S. L. Eber, W. J. Krause, R. H. Freeman, S. H Francis, and J. D. Corbin. 1992. Stimulation of intestinal $\mathrm{Cl}^{-}$transport by heatstable enterotoxin: activation of cAMP-dependent protein kinase by cGMP. Am. J. Physiol. 263:C607-615.

10. Tien, X.-Y., T. A. Brasitus, M. A. Kaetzel, J. R. Dedman, and D. J. Nelson 1994. Activation of the cystic fibrosis transmembrane conductance regulator by cGMP in the human colonic cancer cell line, Caco-2. J. Biol. Chem. 269:51-54.

11. Chao, A. C., F. J. de Sauvage, Y.-J. Dong, J. A. Wagner, D. V. Goeddel, and P. Gardner. 1994. Activation of intestinal CFTR $\mathrm{Cl}^{-}$channel by heat-stable enterotoxin and guanylin via cAMP-dependent protein kinase. EMBO (Eur. Mol Biol. Organ.) J. 13:1065-1072.

12. Wernet, W., V. Flockerzi, and F. Hofmann. 1989. The cDNA of the two isoforms of bovine cGMP-dependent protein kinase. FEBS (Fed. Eur. Biochem. Soc.) Lett. 251:191-196.

13. Sandberg, M., V. Natarajan, I. Ronander, D. Kalderon, U. Walter, S. M. Lohmann, and T. Jahnsen. 1989. Molecular cloning and predicted full-length amino acid sequence of the type $\mathrm{I} \beta$ isozyme of $\mathrm{cGMP}$-dependent protein kinase from human placenta. FEBS (Fed. Eur. Biochem. Soc.) Lett. 255:321-329.

14. Uhler, M. D. 1993. Cloning and expression of a novel cyclic GMP dependent protein kinase from mouse brain. J. Biol. Chem. 268:13586-13591.

15. Jarchau, T., C. Häsler, T. Markert, D. Pöhler, J. Vandekerckhove, H. R. De Jonge, S. M. Lohmann, and U. Walter. 1994. Cloning, expression, and in situ 
localization of rat intestinal cGMP-dependent protein kinase II. Proc. Natl. Acad. Sci. USA. 91:9426-9430.

16. Chomczynski, P., and N. Sacchi. 1987. Single-step method of RNA isolation by acid guanidinium-thiocyanate-phenol-chloroform extraction. Anal. Biochem. 162:156-159.

17. Cox, K. H., D. V. DeLeon, L. M. Angerer, and R. C. Angerer. 1984. Detection of mRNAs in sea urchin embryos by in situ hybridization using asymmetric RNA probes. Dev. Biol. 101:485-502.

18. Studier, W. F., A. H. Rosenberg, J. J. Dunn, and J. W. Dubendorff 1990. Use of T7 RNA polymerase to direct expression of cloned genes. Methods Enzymol. 185:60-89.

19. Horton, R. M., H. D. Hunt, S. N. Ho, J. K. Pullen, and L. R. Pease. 1989. Engineering hybrid genes without the use of restriction enzymes: gene splicing by overlap extension. Gene. 77:61-68.

20. Jarchau, T., T. Chakraborty, F. Garcia, and W. Goebel. 1994. Selection for transport competence of C-terminal polypeptides derived from Escherichia col hemolysin: the shortest peptide capable of autonomous HlyB/HlyD-dependent secretion comprises the C-terminal 62 amino acids of Hly A. Mol. Gen. Genet. 245:53-60.

21. Walter, U., P. Miller, F. Wilson, D. Menkes, and P. Greengard. 1980 Immunological distinction between guanosine $3^{\prime}: 5^{\prime}$-monophosphate-dependent and adenosine $3^{\prime}: 5^{\prime}$-monophosphate-dependent protein kinases. J. Biol. Chem. 255:3757-3762.

22. Harlow, E., and D. Lane. 1988. Antibodies: a laboratory manual. Cold Spring Harbor, New York. 726 pp.

23. De Jonge, H. R. 1975. The response of small intestinal villous and crypt epithelium to cholera toxin in rat and guinea pig. Evidence against a specific role of the crypt cells in choleragen-induced secretion. Biochim. Biophys. Acta. 381:128-143.

24. Van Dommelen, F. S., C. M. Hamer, and H. R. De Jonge. 1986. Efficient entrapment of large and small compounds during vesiculation of intestinal microvilli. Biochem. J. 236:771-778.

25. Veeze, H. J., M. Sinaasappel, J. Bijman, J. Bouquet, and H. R. De Jonge. 1991. Ion transport abnormalities in rectal suction biopsies from children with cystic fibrosis. Gastroenterology. 101:398-403.

26. Vaandrager, A. B., R. Bajnath, J. A. Groot, A. G. M. Bot, and H. R. De Jonge. 1991. $\mathrm{Ca}^{2+}$ and cAMP activate different chloride efflux pathways in HT2919A colonic epithelial cell line. Am. J. Physiol. 261:G958-G965.

27. De Jonge, H. R., and F. S. Van Dommelen. 1981. Cyclic GMP dependent phosphorylation and ion transport in intestinal microvilli. Cold Spring Harbor Conferences on Cell Proliferation. 8:1313-1332.

28. Nobles, M., M. Diener, and W. Rummel. 1991. Segment-specific effects of the heat-stable enterotoxin of $E$. coli on electrolyte transport in the rat colon. Eur. J. Pharmacol. 202:201-211.

29. Butt, E., C. Nolte, S. Schulz, J. Beltman, J. A. Beavo, B. Jastorff, and U. Walter. 1992. Analysis of the functional role of cGMP-dependent protein kinase in intact human platelets using a specific activator 8-para-chlorophenylthio-cGMP. Biochem. Pharmacol. 43:2591-2600.

30. Eigenthaler, M., C. Nolte, M. Halbrügge, and U. Walter. 1992. Concentration and regulation of cyclic nucleotides, cyclic nucleotide dependent protein kinases and one of their major substrates in human platelets. Eur. J. Biochem. 205:471-481.

31. Garbers, D. L. 1992. Guanylyl cyclase receptors and their endocrine, paracrine, and autocrine ligands. Cell. 71:1-4.

32. Cohen, M. B., E. A. Mann, C. Lau, S. J. Henning, and R. A. Giannella. 1992. A gradient in expression of the Escherichia coli heat-stable enterotoxin receptor exists along the villus-to-crypt axis of rat small intestine. Biochem. Biophys. Res. Commun. 186:483-490.

33. Krause, W. J., G. L. Cullingford, R. H. Freeman, S. L. Eber, K. C. Richardson, K. F. Fok, M. G. Currie, and L. R. Forte. 1994. Distribution of heatstable enterotoxin/guanylin receptors in the intestinal tract of man and other mammals. J. Anat. 184:407-417.

34. De Sauvage, F. J., S. Keshav, W.-J. Kuang, N. Gillett, W. Henzel, and D. V. Goeddel. 1992. Precursor structure, expression, and tissue distribution of human guanylin. Proc. Natl. Acad. Sci. USA. 89:9089-9093.

35. Lewis, L. G., D. P. Witte, D. W. Laney, M. G. Currie, and M. B. Cohen. 1993. Guanylin mRNA is expressed in villous enterocytes of the rat small intestine and superficial epithelia of the rat colon. Biochem. Biophys. Res. Commun. 196:553-560.

36. Cetin, Y., M. Kuhn, H. Kulaksiz, K. Adermann, G. Bargsten, D. Grube, and W.-G. Forssmann. 1994. Enterochromaffin cells of the digestive system: cellular source of guanylin, a guanylate cyclase-activating peptide. Proc. Natl. Acad. Sci. USA. 91:2935-2939.

37. Denning, G. M., L. S. Ostedgaard, S. H. Cheng, A. E. Smith, and M. J. Welsh. 1992. Localization of cystic fibrosis transmembrane conductance regulator in chloride secretory epthelia. J. Clin. Invest. 89:339-349.

38. Trezise, A. E. O., and M. Buchwald. 1991. In vivo cell-specific expression of the cystic fibrosis transmembrane regulator. Nature (Lond.). 353:434-437.

39. Strong, T. V., K. Boehm, and F. S. Collins. 1994. Localization of cystic fibrosis transmembrane conductance regulator mRNA in the human gastrointestinal tract by in situ hybridization. J. Clin. Invest. 93:347-354.

40. Siemea, C., and H. Gögelein. 1993. Effects of forskolin on crypt cells of rat distal colon. P fug. Arch. Eur. J. Physiol. 424:321-328.

41. Köckerling, A., and M. Fromm. 1993. Origin of cAMP-dependent $\mathrm{Cl}^{-}$ secretion from both crypts and surface epithelia of rat intestine. Am. J. Physiol. 264:C1294-C1301.

42. Zhou, L., C. R. Dey, S. E. Wert, M. D. Duvall, R. A. Frizzell, and J. A. Whitsett. 1994. Correction of lethal intestinal defect in a mouse model of cystic fibrosis by human CFTR. Science (Wash. DC). 266:1705-1708.

43. Knickelbein, R. G., P. S. Aronson, and J. W. Dobbins. 1988. Membrane distribution of sodium-hydrogen and chloride-bicarbonate exchangers in crypt and villus cell membranes from rabbit ileum. J. Clin. Invest. 82:2158-2163.

44. Yun, C. H. C., S. Gurubhagavatula, S. A. Levine, J. L. M. Montgomery, S. R. Brant, M. E. Cohen, E. J. Cragoe, Jr., J. Pouyssegur, C.-M. Tse, and M. Donowitz. 1993. Glucocorticoid stimulation of ileal $\mathrm{Na}^{+}$absorptive cell brush border $\mathrm{Na}^{+} / \mathrm{H}^{+}$exchange and association with an increase in message for NHE3, an epithelial $\mathrm{Na}^{+} / \mathrm{H}^{+}$exchanger isoform. J. Biol. Chem. 268:206-211.

45. Tse, C.-M., S. R. Brant, M. S. Walker, J. Pouyssegur, and M. Donowitz. 1992. Cloning and sequencing of a rabbit cDNA encoding an intestinal and kidney-specific $\mathrm{Na}^{+} / \mathrm{H}^{+}$exchanger isoform (NHE-3). J. Biol. Chem. 267:93409346.

46. Bookstein, C., A. M. DePaoli, Y. Xie, P. Niu, M. W. Musch, M. C. Rao, and E. B. Chang. 1994. Na ${ }^{+} / \mathrm{H}^{+}$exchangers, NHE-1 and NHE-3, of rat intestine. J. Clin. Invest. $93: 106-113$

47. Semrad, C. E., E. J. Cragoe, Jr., and E. B. Chang. 1990. Inhibition of $\mathrm{Na} /$ $\mathrm{H}$ exchanger in avian intestine by atrial natriuretic factor. J. Clin. Invest. 86:585591 .

48. French, P. J., B. J. Scholte, H. R. De Jonge, and J. Bijman. 1993. Protein kinase G regulation of CFTR. Pediatr. Pulmonol. Suppl. 9:226-227.

49. Berger, H. A., S. M. Travis, and M. J. Welsh. 1993. Regulation of the cystic fibrosis transmembrane conductance regulator $\mathrm{Cl}^{-}$channel by specific protein kinases and protein phosphatases. J. Biol. Chem. 268:2037-2047.

50. Lin, M., A. C., Nairn, and S. E. Guggino. 1992. cGMP-dependent protein kinase regulation of a chloride channel in T84 cells. Am. J. Physiol. 262:C1304C1312. 